\title{
Effects of Chlorella vulgaris as a Feed Ingredient on the Quality and Nutritional Value of Weaned Piglets' Meat
}

\author{
Cátia F. Martins ${ }^{1,2}{ }^{\mathbb{D}}$, José M. Pestana ${ }^{1}$, Cristina M. Alfaia ${ }^{1} \mathbb{D}$, Mónica Costa ${ }^{1} \mathbb{D}$, David M. Ribeiro ${ }^{2} \mathbb{D}$, \\ Diogo Coelho $^{1}\left(\mathbb{D}\right.$, Paula A. Lopes ${ }^{1}\left(\mathbb{D}\right.$, André M. Almeida ${ }^{2}$, João P. B. Freire ${ }^{2}$ and José A. M. Prates ${ }^{1, *(D)}$
}

1 CIISA-Centre for Interdisciplinary Research in Animal Health, Faculdade de Medicina Veterinária, Universidade de Lisboa, 1300-477 Lisbon, Portugal; catiamartins@isa.ulisboa.pt (C.F.M.); jpestana@fmv.ulisboa.pt (J.M.P.); cpmateus@fmv.ulisboa.pt (C.M.A.); monicacosta@fmv.ulisboa.pt (M.C.); diogocoelho@fmv.ulisboa.pt (D.C.); ampalopes@fmv.ulisboa.pt (P.A.L.)

2 LEAF-Linking Landscape, Environment, Agriculture and Food, Instituto Superior de Agronomia, Universidade de Lisboa, 1349-017 Lisbon, Portugal; davidribeiro@isa.ulisboa.pt (D.M.R.); aalmeida@isa.ulisboa.pt (A.M.A.); jpfreire@isa.ulisboa.pt (J.P.B.F.)

* Correspondence: japrates@fmv.ulisboa.pt

\section{check for} updates

Citation: Martins, C.F.; Pestana, J.M. Alfaia, C.M.; Costa, M.; Ribeiro, D.M.; Coelho, D.; Lopes, P.A.; Almeida, A.M.; Freire, J.P.B.; Prates, J.A.M. Effects of Chlorella vulgaris as a Feed Ingredient on the Quality and Nutritional Value of Weaned Piglets' Meat. Foods 2021, 10, 1155. https:// doi.org/10.3390/foods10061155

Academic Editors: Alba Tres, Francesc Guardiola and Ricard Bou

Received: 1 April 2021

Accepted: 18 May 2021

Published: 21 May 2021

Publisher's Note: MDPI stays neutra with regard to jurisdictional claims in published maps and institutional affiliations.

Copyright: (C) 2021 by the authors Licensee MDPI, Basel, Switzerland. This article is an open access article distributed under the terms and conditions of the Creative Commons Attribution (CC BY) license (https:// creativecommons.org/licenses/by/ $4.0 /)$

\begin{abstract}
Chlorella vulgaris $(\mathrm{CH})$ is usually considered a feed supplement in pig nutrition, and its use as an ingredient is poorly studied. Among many interesting characteristics, this microalga has high protein levels and can be a putative alternative for soybean meal. Our aim was to study the effect of a $5 \% \mathrm{CH}$ incorporation in the diet, individually or combined with two carbohydrases, on meat quality traits and nutritional value. Forty-four post-weaned male piglets individually housed, with an initial live weight of $11.2 \pm 0.46 \mathrm{~kg}$, were randomly distributed into four experimental groups: control $(n=11$, without $\mathrm{CH})$ and three groups fed with $5 \% \mathrm{CH}$ incorporation, plain $(n=10)$, with $0.005 \%$ Rovabio $^{\circledR}$ Excel AP $(n=10)$, and with $0.01 \%$ of a pre-selected four-CAZyme mixture $(n=11)$. After two weeks of trial, piglets were slaughtered and longissimus lumborum collected. $\mathrm{CH}$ had no effect on piglets' growth performance. In turn, incorporation of $\mathrm{CH}$ improved the nutritional value of meat by increasing total carotenoids and $n-3$ PUFA content, thus contributing to a more positive $n-6 / n-3$ fatty acid ratio. The supplementation with Rovabio ${ }^{\circledR}$ benefited tenderness and increased overall acceptability of pork. Our results show beyond doubt the viability of the utilization of this microalga as a feed ingredient for swine production.
\end{abstract}

Keywords: Chlorella vulgaris; feed enzymes; weaned piglets; meat quality; nutritional quality

\section{Introduction}

The global population is expected to grow close to approximately 10 billion by 2050, increasing agricultural demand by 50 percent when compared with 2013 [1]. In addition, the growth in income per capita in low- and medium-income countries, and the consequent higher consumption of meat, fruits, and vegetables, will lead to an increase in the land used for agriculture and animal production, with the consequent pressure on natural resources and ecosystems [1]. Among meats, pork is consumed worldwide (36\% of total), with a tendency to increase [2]. The sustainability of monogastric production systems depends, therefore, on the suitability of substitute ingredients to corn and soybean. These crops are considered as the basis of monogastric (poultry and swine) feeding. Indeed, there are numerous issues regarding the sustainability of the feedstuffs, given the fact that they are mostly produced in North and South America and transported to consumer markets, with high economic and environmental costs. Furthermore, they are in direct competition with human nutrition [3].

Microalgae have been studied for several economic applications, including animal feeding [4]. Microalgae can be produced in non-agricultural lands. They are photosynthetic organisms able to efficiently transform atmospheric carbon dioxide into high-value 
products, including carbohydrates, lipids, proteins, and pigments. Therefore, they have promising applications in the food and feed industries [5]. Large-scale cultivation systems and new technologies are currently being developed to turn microalgae cultivation economically feasible [6]. In addition to this challenge, the microalgae cell wall is indigestible by monogastrics. The use of feed enzymes-namely, carbohydrate-active enzyme (CAZymes) that lysate their recalcitrant cell walls-has been demonstrated to be very efficient in improving the nutrient utilization of microalgae by monogastrics [7]. Rovabio ${ }^{\circledR}$ Excel AP is a commercially available CAZyme mixture containing mainly xylanases and $\beta$ glucanases for cereal-based diets. This CAZyme mixture has also been used for microalgaecontaining diets [8,9]. Moreover, a four-CAZyme mixture, consisting of alginate lyase, exo- $\beta$-glucosaminidase, lysozyme, and peptidoglycan $N$-acetylmuramic acid deacetylase, has been shown to partially disrupt the $C$. vulgaris cell wall in vitro [10].

In piglets, weaning is a stressful event derived from social, environmental, and nutritional transitions. In order to decrease the use of antibiotics used to mitigate the piglet post-weaning stress, prebiotics can be a solution. The prebiotic properties of microalgae, in particular the $n$-3 PUFA content, have been studied by different authors [11-13]. For instance, $n$-3 PUFA of microalgae improve the fatty acid composition of animal edible tissues, with recognized beneficial health consequences for both humans and animals.

In addition, spit-roasted piglet is a meat that is consumed worldwide, very popular in Mediterranean Europe, Latin America, Louisiana (USA), China, and several islands of Indonesia and the Pacific. It is particularly consumed on special occasions and at family celebrations, such as Christmas. In Mediterranean Europe, it is a highly valued gourmet food, often considered as a regional specialty. For instance, in Portugal the most popular specialities are Leitão da Bairrada and Leitão de Negrais, whereas in Spain the Cochinillo Asado is a reputed specialty of the Castilla-León region. Finally, body composition at the end of post-weaning determines production performance at the growing-finishing period and body composition when pigs achieve $100 \mathrm{~kg}$ of body weight [14,15].

This work aimed to study the dietary incorporation of $5 \%$ of C. vulgaris, with or without exogenous enzymes, on meat quality characteristics and nutritional significance of piglets. We assessed $\mathrm{pH}$, color, lipid oxidation, sensorial qualities, fatty acid composition, and pigment profile. We hypothesized that $C$. vulgaris can be a viable ingredient in piglet feeding by improving the digestibility of valuable microalga nutrients without negatively affecting animal performance and meat traits.

\section{Materials and Methods}

\subsection{Animals and Experimental Diets}

The animal trial was performed at ISA-Instituto Superior de Agronomia (University of Lisbon, Lisbon, Portugal) facilities. All the procedures were reviewed by the Ethics Commission of ISA and accepted by the Animal Care Committee of the National Veterinary Authority (Direção Geral de Alimentação e Veterinária, Lisbon, Portugal), in accordance with the European Union legislation (2010/63/EU Directive). We selected forty-four castrated male piglets from Large White $\times$ Landrace sows crossed with Pietrain boars; they were weaned at 28 days of age and had an initial body weight of $11.2 \pm 0.46 \mathrm{~kg}$ (mean $\pm \mathrm{SD}$ ). The piglets were single housed in metabolic cages $(1000 \times 500 \times 480 \mathrm{~mm})$. During the adaptation period of two days, to minimize stress and stabilize all metabolic conditions, two animals failed to adapt and were not considered in the experiment. The remaining piglets were arbitrarily distributed in 4 experimental groups: Control $(n=11$, cereal and soybean meal-based diet), $\mathrm{CH}(n=10$, control diet with $5 \%$ C. vulgaris $), \mathrm{CH}+\mathrm{R}(n=10$, control diet with $5 \%$ C. vulgaris and $0.005 \%$ Rovabio ${ }^{\circledR}$ Excel AP from Adisseo (Antony, France) $)$, and $\mathrm{CH}+\mathrm{M}(n=11$, control diet with $5 \% \mathrm{C}$. vulgaris supplemented and $0.01 \%$ of a pre-selected four-CAZyme mixture (previously described by Coelho et al. [10])). C. vulgaris was produced as described in detail by Coelho et al. [10]. Then, this microalga was supplied as freeze-dried powder (Allmicroalgae-Natural Products SA, Pataias, Portugal) 
and incorporated in the diets. Rovabio ${ }^{\circledR}$ Excel AP was incorporated in the diet at a $0.005 \%$ level following the manufacturer's recommendation.

Diets were dried at $103{ }^{\circ} \mathrm{C}$ to constant weight to assess dry matter (DM). Crude protein of diets was determined following the method 954.01 [16] utilizing the factor $6.25 \times$ nitrogen content $(\mathrm{N})$ calculated by the Kjeldahl procedure. Crude fat of diets was assessed by an automatic Soxhlet extraction with petroleum ether (Gerhardt Analytical Systems, Königswinter, Germany). Ash content of the experimental diets was assessed following the 942.05 [16] method. Neutral detergent fiber (NDF) and acid detergent fiber (ADF) were determined by 989.03 [16] method. Metabolizable energy (ME) was estimated in accordance with Noblet et al. [17]. Fatty acids were determined by one-step extraction and converted to fatty acid methyl esters (FAME) through acid transesterification and gas chromatography (GC) having heneicosanoic acid (21:0) methyl ester as the internal standard [18]. $\beta$-Carotene and tocopherols of diets were determined by direct saponification, with a single $n$-hexane extraction followed by HPLC, based on the external standard technique from a standard curve of peak area vs. concentration, as previously reported [19]. The determination of pigments in diets was carried out in accordance with Teimouri et al. [20], with minor alterations. In brief, diets $(0.5 \mathrm{~g})$ were incubated at room temperature with acetone overnight under agitation and in the dark. Following on extraction, samples were subjected to centrifugation at $4000 \mathrm{rpm}$ during $5 \mathrm{~min}$ and analyzed by UV/Vis spectrophotometry (Ultrospec 3100; Amersham Biosciences, Little Chalfont, UK). The concentration of pigments was assessed using methodologies described by Hynstova et al. [21] equations. All diets were formulated to have $3440 \mathrm{kcal} \mathrm{ME} / \mathrm{kg}$ of energy and $19.5 \%$ of crude protein, as fed basis. The ingredients and chemical composition of diets are shown in Table 1 . The detailed chemical composition of C. vulgaris was previously described [9].

\subsection{Productive Parameters}

Throughout the animal trial, feed and refusals were recorded daily. Animals were weighed once a week before feeding to calculate average daily feed intake (ADFI), average daily weight gain (ADG), and feed conversion ratio (FCR). After 15 days of the experiment, piglets were slaughtered at a body weight of $23.1 \pm 2.56 \mathrm{~kg}$, through electrical stunning followed by exsanguination, in accordance with standard protocols applied in commercial abattoirs. Longissimus lumborum muscle samples were extracted from both sides of the carcass, between the third and fifth lumbar vertebrae. Muscle samples from the left carcass side were collected, minced, vacuum packed, and stored at $-20^{\circ} \mathrm{C}$ for intramuscular fat and fatty acid profile and for total pigments and tocopherol profile determinations. For TBARS analysis, muscles samples were stored at $-80^{\circ} \mathrm{C}$. Muscle samples from the right carcass side were stored at $4{ }^{\circ} \mathrm{C}$ during $24 \mathrm{~h}$ for color and $\mathrm{pH}$ determinations. Then, the samples were vacuum packed and frozen at $-20^{\circ} \mathrm{C}$ until cooking loss, shear force, and sensory analyses.

\subsection{Determination of Meat Quality Traits}

The $\mathrm{pH}$ of longissimus lumborum at $24 \mathrm{~h}$ postmortem was measured using a $\mathrm{pH}$ meter with a glass penetrating electrode from Hanna Instruments (Woonsocket, RI, USA) and was determined as an average of 3 replicates. Meat color variables, such as lightness $\left(\mathrm{L}^{*}\right)$, redness $\left(\mathrm{a}^{*}\right)$, and yellowness $\left(\mathrm{b}^{*}\right)$ were measured $24 \mathrm{~h}$ postmortem on 3 spots of cut surface of the longissimus lumborum samples using a colorimeter (Minolta CR-300; Konica Minolta, Tokyo, Japan) after $1 \mathrm{~h}$ at $4{ }^{\circ} \mathrm{C}$. Lipid oxidation of meat was assessed by thiobarbituric acid reactive substances (TBARS) at days 0 and 8 , stored at $4{ }^{\circ} \mathrm{C}$, following the procedure of Grau et al. [22]. TBARS were calculated in duplicate from a standard curve of 1,1,3,3-tetraethoxypropane (Fluka, Neu Ulm, Germany) and expressed as mg of malondialdehyde $/ \mathrm{kg}$ of muscle. 
Table 1. Ingredients and chemical composition of experimental diets.

\begin{tabular}{|c|c|c|c|c|}
\hline \multirow[b]{2}{*}{ Item } & \multicolumn{4}{|c|}{ Diets } \\
\hline & Control & $\mathrm{CH}$ & $\mathrm{CH}+\mathrm{R}$ & $\mathbf{C H}+\mathrm{M}$ \\
\hline \multicolumn{5}{|l|}{ Ingredients ( $\%$ as fed basis) } \\
\hline Wheat & 43.9 & 44.0 & 44.0 & 44.0 \\
\hline Corn & 15.0 & 15.0 & 15.0 & 15.0 \\
\hline Soybean meal 48 & 25.0 & 20.0 & 20.0 & 20.0 \\
\hline Whey powder & 10.0 & 10.0 & 10.0 & 10.0 \\
\hline Soybean oil & 3.00 & 3.00 & 3.00 & 3.00 \\
\hline Chlorella vulgaris & 0 & 5.00 & 5.00 & 5.00 \\
\hline Rovabio ${ }^{\circledR}$ Excel AP & 0 & 0 & 0.005 & 0 \\
\hline Four-CAZyme mixture & 0 & 0 & 0 & 0.01 \\
\hline Energy (kcal ME $1 / k^{k g}$ as fed basis) & 3428 & 3436 & 3449 & 3449 \\
\hline \multicolumn{5}{|l|}{ Proximate composition ( $\%$ as fed basis) } \\
\hline Dry matter & 90.5 & 90.8 & 90.8 & 90.9 \\
\hline Crude protein & 19.3 & 19.2 & 19.5 & 19.4 \\
\hline Crude fat & 5.29 & 5.39 & 5.39 & 5.63 \\
\hline Ash & 5.43 & 5.65 & 5.47 & 5.60 \\
\hline NDF & 12.9 & 11.9 & 12.9 & 10.4 \\
\hline ADF & 2.76 & 2.45 & 2.58 & 2.54 \\
\hline \multicolumn{5}{|l|}{ Fatty acid composition ( $\%$ total fatty acids) } \\
\hline $14: 0$ & 0.351 & 0.380 & 0.380 & 0.361 \\
\hline 16:0 & 10.6 & 11.0 & 10.9 & 11.1 \\
\hline $16: 1 n-7$ & 0.158 & 0.903 & 0.900 & 0.677 \\
\hline 17:0 & 0.095 & 0.104 & 0.103 & 0.104 \\
\hline $17: 1 n-8$ & 0.040 & 0.583 & 0.643 & 0.828 \\
\hline 18:0 & 3.35 & 3.33 & 3.38 & 3.26 \\
\hline $18: 1 n-9$ & 24.8 & 24.5 & 24.5 & 24.6 \\
\hline $18: 1 n-7$ & 0.909 & 1.16 & 1.16 & 1.10 \\
\hline $18: 2 n-6$ & 55.8 & 53.3 & 53.2 & 52.9 \\
\hline $18: 3 n-3$ & 1.55 & 2.18 & 2.23 & 2.52 \\
\hline \multicolumn{5}{|l|}{$\beta$-Carotene and tocopherol profile $(\mu \mathrm{g} / \mathrm{g})$} \\
\hline$\beta$-Carotene & n.d. & 13.3 & 13.7 & 14.5 \\
\hline$\alpha$-Tocopherol & 28.6 & 19.9 & 22.1 & 24.2 \\
\hline$\beta$-Tocopherol & 1.11 & 1.10 & 1.00 & 1.12 \\
\hline$\gamma$-Tocopherol & 2.52 & 2.00 & 2.21 & 2.11 \\
\hline$\delta$-Tocopherol & 0.502 & 0.334 & 0.387 & 0.396 \\
\hline$\alpha$-Tocotrienol & 3.43 & 3.73 & 3.58 & 3.53 \\
\hline$\gamma$-Tocotrienol & 1.38 & 1.51 & 1.69 & 1.46 \\
\hline \multicolumn{5}{|l|}{ Pigments $(\mu \mathrm{g} / g)$} \\
\hline Chlorophyll-a $^{2}$ & 3.38 & 109 & 130 & 135 \\
\hline Chlorophyll-b ${ }^{3}$ & 6.05 & 31.9 & 42.6 & 39.8 \\
\hline Total chlorophylls 4 & 9.43 & 141 & 172 & 174 \\
\hline Total carotenoids 5 & 2.67 & 36.9 & 44.5 & 52.9 \\
\hline Total chlorophylls and total carotenoids ${ }^{6}$ & 12.1 & 178 & 217 & 227 \\
\hline
\end{tabular}

Dietary treatments: $\mathrm{CH}$, Chlorella vulgaris diet; $\mathrm{CH}+\mathrm{R}, \mathrm{C}$. vulgaris diet supplemented with $0.005 \%$ of Rovabio ${ }^{\circledR}$ Excel AP; $\mathrm{CH}+\mathrm{M}, \mathrm{C}$. vulgaris diet supplemented with $0.01 \%$ of four-CAZyme mixture. ADF, acid detergent fiber; $\mathrm{NDF}$, neutral detergent fiber; ME, metabolizable energy; n.d., not detected. ${ }^{1}$ Metabolizable energy $(\mathrm{kcal} / \mathrm{kg} \mathrm{DM})$ $=4412-11.06 \times$ ash $(\mathrm{g} / \mathrm{kg} \mathrm{DM})+3.37 \times$ crude fat $(\mathrm{g} / \mathrm{kg} \mathrm{DM})-5.18 \times \mathrm{ADF}(\mathrm{g} / \mathrm{kg} \mathrm{DM}) .{ }^{2} \mathrm{Ca}=11.24 \mathrm{~A}_{662}-$ $2.04 \mathrm{~A}_{645} \cdot{ }^{3} \mathrm{Cb}=20.13 \mathrm{~A}_{645}-4.19 \mathrm{~A}_{662} \cdot{ }^{4} \mathrm{Ca}+\mathrm{b}=7.05 \mathrm{~A}_{662}+18.09 \mathrm{~A}_{645} \cdot{ }^{5} \mathrm{Cx}+\mathrm{c}=\left(1000 \mathrm{~A}_{470}-1.90 \mathrm{Ca}-63.14\right.$ $\mathrm{Cb}) / 214 .{ }^{6}(\mathrm{Ca}+\mathrm{b})+(\mathrm{Cx}+\mathrm{c})$. Bolded words thorought the table are topic headings.

\subsection{Determination of Cooking Loss and Shear Force}

Meat samples were thawed at $4{ }^{\circ} \mathrm{C}$ overnight and cooked using a water bath at $80^{\circ} \mathrm{C}$ until reaching $78^{\circ} \mathrm{C}$ of internal temperature, monitored by a thermocouple (Lufft C120; Lufft, München, Germany). After 2 h cooling at room temperature, samples were longitudinally cut toward the fibers with a $1 \mathrm{~cm}^{2}$ cross-section for cooking loss and shear force. Before and after cooking, meat samples were weighed to determine cooking loss. Meat shear force was determined using a Warner-Bratzler blade coupled to a texture 
analyzer (TA-XT Plus texture analyzer; Stable Micro Systems, Surrey, UK) and is expressed as the mean of the peak value of a minimum of 4 replicate measurements.

\subsection{Trained Sensory Panel Analysis}

Trained sensory analysis was carried out in muscle samples, trimmed of external connective tissue, cut into cubes with approximately $1 \mathrm{~cm}^{3}$, and cooked in a water bath, as previously mentioned for cooking loss. Samples were arbitrarily allocated across 5 panel sessions, with 8 random samples per session. The attributes were tenderness, juiciness, flavor, off-flavor, and overall acceptability in a numeric scale from 1 to 8 , in which 1 was the low/negative score and 8 was the high/positive score. For off-flavor, the scale applied was from 0 (absence) to 8 (maximum). The sensory panel consisted of thirteen panelists, selected after intensive training, according to Cross et al. [23].

\subsection{Determination of Intramuscular Fat and Fatty Acid Profile}

Intramuscular fat from lyophilized longissimus lumborum samples was extracted according to Folch et al. [24], utilizing dichloromethane-methanol $(2: 1, v / v)$ as reported by Carlson [25], and measured gravimetrically by weighing the fatty residue after solvent evaporation. Fatty acids were converted to FAME through a combined alkaline and acid sequential transesterification, in accordance with Raes et al. [26]. The fatty acid composition was analyzed by GC (HP6890A; Hewlett-Packard, Avondale, PA, USA), equipped with a flame ionization detector, as described [9]. The identification of FAME was achieved using a reference standard (FAME mixture of 37 compounds, Supelco Inc., Bellefonte, PA, USA) corroborated by GC along with mass spectrometry using a GC-MS QP2010-Plus (Shimadzu, Kyoto, Japan). FAME calculation was based on the internal standard technique with heneicosanoic acid (21:0). Fatty acids are expressed as a percentage of the sum of identified fatty acids.

\subsection{Determination of Total Pigments, Cholesterol, and Tocopherols}

Chlorophyll a, chlorophyll $\mathrm{b}$, and total carotenoids contents were quantified in meat, in accordance with Teimouri et al. [20]. Samples were subjected to incubation overnight with acetone (Merck KGaA, Darmstadt, Germany) and agitation at room temperature in the dark. Following on centrifugation, the absorbance was read at a UV/Vis spectrophotometer (Ultrospec 3100 pro; Amersham Biosciences, Little Chalfont, UK) and results were determined in accordance with Hynstova et al. [21]. The parallel quantification of total cholesterol, $\beta$-Carotene, and tocopherols, in duplicate, in meat samples was carried out, according to Prates et al. [19].

\subsection{Statistics}

All data were analyzed with the PROC GLM of SAS software package (version 9.4; SAS Institute Inc., Cary, NC, USA). Data were checked for normal distribution and variance homogeneity. The statistical model assumed the dietary treatment as the single effect and the piglet as the experimental unit. When significant effects of dietary treatments were observed, least-squares means for multiple comparisons were generated using the PDIFF option adjusted with Tukey-Kramer method. Results were considered significantly different at $p<0.05$.

\section{Results}

\subsection{Zootechnical Parameters}

Table 2 shows results on growth performance parameters and feed intake of piglets. Diets had no significant effect on growth performance variables, such as final live weight, ADG, and FCR $(p>0.05)$. The reference group had lower ADFI than groups fed with $C$. vulgaris $(p=0.008)$, although this difference had no impact on piglets' growth. 
Table 2. Effect of experimental diets on feed intake and growth performance of piglets.

\begin{tabular}{|c|c|c|c|c|c|c|}
\hline & \multicolumn{4}{|c|}{ Diets } & \multirow[b]{2}{*}{ SEM } & \multirow[b]{2}{*}{$p$-Value } \\
\hline & Control & $\mathrm{CH}$ & $\mathrm{CH}+\mathrm{R}$ & $\mathbf{C H}+\mathbf{M}$ & & \\
\hline Initial live weight (kg) & 11.1 & 11.1 & 11.3 & 11.2 & 0.105 & 0.851 \\
\hline Final live weight (kg) & 22.3 & 23.3 & 23.5 & 23.1 & 0.247 & 0.349 \\
\hline ADFI (g) 1 & $768^{a}$ & $852^{b}$ & $857^{\mathrm{b}}$ & $856^{\mathrm{b}}$ & 11.6 & 0.008 \\
\hline $\operatorname{ADG}(g)^{2}$ & 535 & 581 & 579 & 569 & 8.50 & 0.189 \\
\hline FCR $^{3}$ & 1.44 & 1.47 & 1.48 & 1.51 & 0.013 & 0.282 \\
\hline
\end{tabular}

Dietary treatments: $\mathrm{CH}$, Chlorella vulgaris diet; $\mathrm{CH}+\mathrm{R}, \mathrm{C}$. vulgaris diet supplemented with $0.005 \%$ of Rovabio ${ }^{\circledR}$ Excel AP; $\mathrm{CH}+\mathrm{M}, \mathrm{C}$. vulgaris diet supplemented with $0.01 \%$ of four-CAZyme mixture. ${ }^{1} \mathrm{ADFI}$, average daily feed intake. ${ }^{2}$ ADG, average daily weight gain. ${ }^{3}$ FCR, feed conversion ratio. ${ }^{a}, b$ Values with different superscript letters in the same row are significantly different $(p<0.05)$. Bolded words thorought the table are topic headings.

\subsection{Meat Quality Traits}

3.2.1. $\mathrm{pH}$, Color, and Susceptibility to Lipid Oxidation

The impact of experimental diets on meat quality traits from piglets is shown in Table 3. Diets did not affect $\mathrm{pH} 24 \mathrm{~h}$ postmortem and color parameters $(p>0.05)$. Although TBARS were not detected in meat at day 0 , their levels were diminished in the reference group relative to $\mathrm{CH}+\mathrm{M}(0.151$ vs. $0.805 \mathrm{mg}$ of malondialdehyde $/ \mathrm{kg}$ of muscle, respectively) after 8 days under refrigeration $(p=0.019)$.

Table 3. Effect of experimental diets on $\mathrm{pH} 24 \mathrm{~h}, \mathrm{CIE}$ color parameters $\left(\mathrm{L}^{*}, \mathrm{a}^{*}, \mathrm{~b}^{*}\right)$ and TBARS levels (mg malondialdehyde/ $\mathrm{kg}$ muscle) after 0 and 8 days under refrigeration in longissimus lumborum muscle.

\begin{tabular}{ccccccc}
\hline & \multicolumn{7}{c}{ Diets } \\
\cline { 2 - 7 } & Control & $\mathbf{C H}$ & $\mathbf{C H}+\mathbf{R}$ & $\mathbf{C H}+\mathbf{M}$ & $\mathbf{S E M}$ & $p$-Value \\
\hline pH 24 h & 5.61 & 5.54 & 5.57 & 5.61 & 0.033 & 0.401 \\
Color & & & & & & \\
L $^{*}$ & 48.6 & 48.6 & 48.5 & 47.3 & 0.810 & 0.582 \\
a $^{*}$ & 6.20 & 6.50 & 6.79 & 7.26 & 0.321 & 0.112 \\
b $^{*}$ & -0.528 & -0.157 & -0.391 & -0.821 & 0.2458 & 0.275 \\
TBARS & & & & & & \\
Day 0 & n.d. & n.d. & n.d. & n.d. & - & - \\
Day 8 & $0.151^{\text {a }}$ & $0.752^{\text {ab }}$ & $0.621^{\text {ab }}$ & $0.805^{\text {b }}$ & 0.161 & 0.019 \\
\hline
\end{tabular}

Dietary treatments: $\mathrm{CH}$, Chlorella vulgaris diet; $\mathrm{CH}+\mathrm{R}, \mathrm{C}$. vulgaris diet supplemented with $0.005 \%$ of Rovabio ${ }^{\circledR}$ Excel AP; $\mathrm{CH}+\mathrm{M}, \mathrm{C}$. vulgaris diet supplemented with $0.01 \%$ of four-CAZyme mixture. ${ }^{1}$ TBARS-thiobarbituric acid reactive substances; $n$.d., not detected $\left(<0.020 \mathrm{mg}\right.$ malondialdehyde $/ \mathrm{kg}$ muscle). ${ }^{\mathrm{a}, \mathrm{b}}$ Values with different superscript letters in the same row are significantly different $(p<0.05)$. Bolded words thorought the table are topic headings.

\subsubsection{Cooking Loss, Shear Force, and Sensory Panel Analysis}

Table 4 shows the impact of experimental diets on cooking loss, shear force, and sensory panel analysis of meat. Cooking loss had a statistically higher value in the control group compared with the $\mathrm{CH}+\mathrm{M}$ group $(p=0.011)$. Shear force was unaffected by diets $(p>0.05)$. Juiciness, flavor, and off-flavor presented no significant differences among diets $(p>0.05)$. However, for tenderness, the $\mathrm{CH}+\mathrm{R}$ group showed the tenderest meat $(p<0.001)$. In line with this finding, the overall acceptability was higher in the $\mathrm{CH}+\mathrm{R}$ muscle compared with the other diets $(p=0.000)$. 
Table 4. Effect of experimental diets on cooking loss (\%), shear force $(\mathrm{kg})$ and sensory panel analysis in longissimus lumborum.

\begin{tabular}{ccccccc}
\hline & \multicolumn{7}{c}{ Diets } \\
\cline { 2 - 7 } & Control & $\mathbf{C H}$ & $\mathbf{C H}+\mathbf{R}$ & $\mathbf{C H}+\mathbf{M}$ & SEM & $p$-Value \\
\hline Cooking loss & $28.5^{\mathrm{b}}$ & $27.5^{\mathrm{ab}}$ & $25.5^{\mathrm{ab}}$ & $24.7^{\mathrm{a}}$ & 0.881 & 0.011 \\
Shear force & 3.99 & 4.04 & 3.68 & 4.29 & 0.269 & 0.466 \\
Sensory panel scores & & & & & & \\
Tenderness & $4.95^{\mathrm{a}}$ & $5.10^{\mathrm{a}}$ & $5.69^{\mathrm{b}}$ & $5.04^{\mathrm{a}}$ & 0.121 & $<0.001$ \\
Juiciness & 5.08 & 5.34 & 5.48 & 5.21 & 0.109 & 0.056 \\
Flavor & 4.90 & 4.92 & 4.96 & 4.96 & 0.111 & 0.965 \\
Off-flavor & 0.276 & 0.362 & 0.298 & 0.378 & 0.0764 & 0.714 \\
Overall acceptability & $4.91^{\mathrm{a}}$ & $5.09^{\mathrm{a}}$ & $5.54^{\mathrm{b}}$ & $5.03^{\mathrm{a}}$ & 0.112 & 0.000
\end{tabular}

Dietary treatments: $\mathrm{CH}$, Chlorella vulgaris diet; $\mathrm{CH}+\mathrm{R}, \mathrm{C}$. vulgaris diet supplemented with $0.005 \%$ of Rovabio ${ }^{\circledR}$ Excel AP; $\mathrm{CH}+\mathrm{M}, \mathrm{C}$. vulgaris diet supplemented with $0.01 \%$ of four-CAZyme mixture. ${ }^{\mathrm{a}, \mathrm{b}}$ Values with different superscript letters in the same row are significantly different $(p<0.05)$. Bolded words thorought the table are topic headings.

\subsection{Intramuscular Fat, Total Cholesterol, and Fatty Acid Profile of Meat}

The impact of experimental diets on intramuscular fat, total cholesterol, and fatty acid profile of longissimus lumborum muscle samples is shown in Table 5. Intramuscular fat and cholesterol contents were unaffected by diets $(p>0.05)$. Dietary treatments influenced only a few fatty acids, specifically 15:0, 17:0, 17:1n-8, 18:0, 20:1n-9, 20:2n-6, 22:1n-9, 22:5n-3, and 22:6n-3. Compared with Chlorella-fed piglets, the control group had a higher percentage of 15:0 ( $p<0.0001), 17: 0(p<0.001)$, and 17:1n-8 $(p<0.001)$. Interestingly, stearic acid (18:0) was lower in control and $\mathrm{CH}+\mathrm{M}$ groups in comparison with the other groups $(p=0.023)$. In contrast, the proportion of 20:2n-6 increased in piglets fed control and $\mathrm{CH}+$ $\mathrm{M}$ diets $(p=0.004)$. Additionally, the reference group had a higher proportion of 20:1n-9 $(p=0.009)$ but a lower proportion of 22:1n-9 $(p=0.004)$ than piglets fed $\mathrm{CH}$. Conversely, the proportions of 22:5n-3 (DPA, docosapentaenoic acid) $(p<0.001)$ and 22:6n-3 (DHA, docosahexaenoic acid) $(p=0.001)$ were enhanced in piglets fed $\mathrm{CH}$ and $\mathrm{CH}+\mathrm{M}$. Indeed, both DPA and DHA increased at least 1.79-fold and 2.35-fold in $\mathrm{CH}$ and $\mathrm{CH}+\mathrm{M}$ groups, respectively.

Concerning the partial sums and ratios of fatty acids, only the $n-3$ PUFA sum was enhanced in $\mathrm{CH}$ and $\mathrm{CH}+\mathrm{M}$ groups $(p<0.001)$ compared with the other groups. The remaining partial sums of fatty acids, as well as the PUFA/SFA ratio, were similar across all dietary treatments $(p>0.05)$. Nevertheless, the $n-6 / n-3$ ratio was reduced in microalga-fed groups in comparison with the control group $(p<0.001)$.

\subsection{Total Pigments and Tocopherol Profile of Meat}

Total carotenoids, chlorophylls, and tocopherols of longissimus lumborum samples are shown in Table 6. The pigment contents and tocopherol profile were identical for all dietary treatments $(p>0.05)$, expect for total carotenoids. Meat from Chlorella-fed piglets had values of total carotenoids 2 times higher than the reference group $(p=0.002)$. $\beta$-Carotene was undetected in any of the groups. 
Table 5. Effect of experimental diets on intramuscular fat content ( $\mathrm{g} / 100 \mathrm{~g}$ muscle), total cholesterol (mg/100 g muscle), and fatty acid (FA) composition (\% of total FA) in longissimus lumborum.

\begin{tabular}{|c|c|c|c|c|c|c|}
\hline & \multicolumn{5}{|c|}{ Diets } & \multirow[b]{2}{*}{$p$-Value } \\
\hline & Control & $\mathrm{CH}$ & $\mathbf{C H}+\mathrm{R}$ & $\mathbf{C H}+\mathbf{M}$ & SEM & \\
\hline Intramuscular fat & 1.36 & 1.14 & 1.31 & 1.35 & 0.078 & 0.159 \\
\hline Total cholesterol & 54.8 & 53.4 & 44.4 & 48.4 & 0.029 & 0.058 \\
\hline \multicolumn{7}{|l|}{ Fatty acid composition } \\
\hline $10: 0$ & 0.024 & 0.028 & 0.032 & 0.019 & 0.005 & 0.204 \\
\hline $12: 0$ & 0.046 & 0.049 & 0.047 & 0.054 & 0.005 & 0.660 \\
\hline 14:0 & 0.839 & 0.826 & 0.943 & 0.948 & 0.091 & 0.661 \\
\hline $14: 1 n-5$ & 0.015 & 0.015 & 0.015 & 0.012 & 0.003 & 0.924 \\
\hline 15:0 & $0.310^{\mathrm{b}}$ & $0.149^{a}$ & $0.128^{a}$ & $0.135^{\mathrm{a}}$ & 0.028 & $<0.001$ \\
\hline DMA-16:0 & 0.128 & 0.131 & 0.122 & 0.136 & 0.022 & 0.974 \\
\hline 16:0 & 21.7 & 23.8 & 24.5 & 23.7 & 1.03 & 0.244 \\
\hline $16: 1 n-9$ & 0.442 & 0.510 & 0.468 & 0.487 & 0.017 & 0.043 \\
\hline $16: 1 n-7$ & 2.11 & 1.95 & 2.51 & 2.24 & 0.170 & 0.139 \\
\hline 17:0 & $1.25^{\mathrm{b}}$ & $0.730^{\mathrm{a}}$ & $0.620^{a}$ & $0.710^{a}$ & 0.122 & 0.001 \\
\hline $17: 1 n-8$ & $0.864^{b}$ & $0.500^{\mathrm{a}}$ & $0.451^{\mathrm{a}}$ & $0.467^{\mathrm{a}}$ & 0.080 & 0.001 \\
\hline DMA-18:0 & 0.030 & 0.039 & 0.027 & 0.043 & 0.006 & 0.210 \\
\hline DMA-18:1 & 0.029 & 0.053 & 0.036 & 0.047 & 0.009 & 0.203 \\
\hline 18:0 & $12.7^{\mathrm{a}}$ & $14.3^{b}$ & $14.3^{b}$ & $13.8^{\mathrm{ab}}$ & 0.427 & 0.023 \\
\hline $18: 1 n-9$ & 28.8 & 26.8 & 30.1 & 29.0 & 1.26 & 0.314 \\
\hline $18: 1 n-7$ & 3.35 & 3.31 & 3.25 & 3.26 & 0.073 & 0.717 \\
\hline $18: 2 n-6$ & 19.3 & 17.9 & 15.9 & 16.7 & 1.85 & 0.558 \\
\hline $18: 2 t 9 t 12$ & 0.074 & 0.070 & 0.074 & 0.073 & 0.007 & 0.979 \\
\hline $18: 3 n-6$ & 0.131 & 0.149 & 0.106 & 0.113 & 0.020 & 0.431 \\
\hline $18: 3 n-3$ & 0.382 & 0.358 & 0.378 & 0.424 & 0.050 & 0.809 \\
\hline 20:0 & 0.187 & 0.210 & 0.187 & 0.190 & 0.010 & 0.333 \\
\hline $20: 1 n-9$ & $0.586^{b}$ & $0.463^{\mathrm{a}}$ & $0.543^{a b}$ & $0.514^{\mathrm{ab}}$ & 0.025 & 0.009 \\
\hline $20: 2 n-6$ & $0.720^{b}$ & $0.487^{\mathrm{a}}$ & $0.465^{\mathrm{a}}$ & $0.514^{\mathrm{ab}}$ & 0.053 & 0.004 \\
\hline $20: 3 n-6$ & 0.369 & 0.358 & 0.251 & 0.295 & 0.054 & 0.363 \\
\hline $20: 4 n-6$ & 2.69 & 3.07 & 1.64 & 2.11 & 0.462 & 0.150 \\
\hline $20: 3 n-3$ & 0.056 & 0.051 & 0.057 & 0.051 & 0.007 & 0.868 \\
\hline $20: 5 n-3$ & 0.053 & 0.082 & 0.060 & 0.065 & 0.009 & 0.139 \\
\hline 22:0 & 0.083 & 0.110 & 0.092 & 0.085 & 0.009 & 0.171 \\
\hline $22: 1 n-9$ & $0.050^{\mathrm{a}}$ & $0.093^{b}$ & $0.069 \mathrm{ab}$ & $0.065^{a b}$ & 0.008 & 0.004 \\
\hline $22: 2 n-6$ & 0.040 & 0.040 & 0.035 & 0.032 & 0.007 & 0.766 \\
\hline $22: 5 n-3$ & $0.275^{\mathrm{a}}$ & $0.595^{\mathrm{b}}$ & $0.231^{\mathrm{a}}$ & $0.491^{b}$ & 0.056 & $<0.001$ \\
\hline $22: 6 n-3$ & $0.305^{\mathrm{a}}$ & $0.889^{b}$ & $0.621^{a b}$ & $0.716^{b}$ & 0.096 & 0.001 \\
\hline 23:0 & 0.155 & 0.254 & 0.181 & 0.202 & 0.026 & 0.062 \\
\hline Others & 1.89 & 1.63 & 1.56 & 2.35 & 0.299 & 0.229 \\
\hline \multicolumn{7}{|l|}{$\begin{array}{l}\text { Partial sums of fatty } \\
\text { acids }\end{array}$} \\
\hline$\sum \mathrm{SFA}^{1}$ & 37.3 & 40.4 & 41.0 & 39.8 & 1.29 & 0.173 \\
\hline$\sum$ MUFA $^{2}$ & 36.2 & 33.6 & 37.4 & 36.0 & 1.40 & 0.288 \\
\hline$\sum$ PUFA $^{3}$ & 24.4 & 24.1 & 19.8 & 21.6 & 2.36 & 0.458 \\
\hline$\sum n-3$ PUFA $^{4}$ & $1.07^{\mathrm{a}}$ & $1.97^{b}$ & $1.35^{\mathrm{a}}$ & $1.75^{b}$ & 0.101 & $<0.001$ \\
\hline$\sum n-6$ PUFA $^{5}$ & 23.3 & 22.0 & 18.4 & 19.8 & 2.38 & 0.453 \\
\hline \multicolumn{7}{|l|}{ Ratios of fatty acids } \\
\hline PUFA/SFA & 0.661 & 0.632 & 0.491 & 0.573 & 0.075 & 0.386 \\
\hline$n-6 / n-3$ & $21.9^{b}$ & $11.7^{\mathrm{a}}$ & $13.5^{\mathrm{a}}$ & $12.7^{\mathrm{a}}$ & 1.51 & $<0.001$ \\
\hline
\end{tabular}

Dietary treatments: $\mathrm{CH}$, Chlorella vulgaris diet; $\mathrm{CH}+\mathrm{R}, \mathrm{C}$. vulgaris diet supplemented with $0.005 \%$ of Rovabio ${ }^{\circledR}$ Excel AP; $\mathrm{CH}+\mathrm{L}, \mathrm{C}$. vulgaris diet supplemented with $0.01 \%$ of four-CAZyme mixture. SEM, standard error of the mean; FA, fatty acids; DMA, dimethylacetal; SFA, saturated fatty acids; MUFA, monounsaturated fatty acids; PUFA, polyunsaturated fatty acids. ${ }^{1} 10: 0+12: 0+14: 0+15: 0+16: 0+17: 0+18: 0+20: 0+22: 0+23: 0 .{ }^{2} 14: 1 n-5$ $+16: 1 n-9+16: 1 n-7+17: 1 n-8+18: 1 n-9+18: 1 n-7+20: 1 n-9+22: 1 n-9 .{ }^{3} 18: 2 n-6+18: 3 n-6+18: 3 n-3+20: 2 n-6+$ $20: 3 n-6+20: 4 n-6+20: 3 n-3+20: 5 n-3+22: 2 n-6+22: 5 n-3+22: 6 n-3 .{ }^{4} 18: 3 n-3+20: 3 n-3+20: 5 n-3+22: 5 n-3+22: 6 n-3$. ${ }^{5} 18: 2 n-6+18: 3 n-6+20: 2 n-6+20: 3 n-6+20: 4 n-6 .{ }^{a}, \mathrm{~b}$ Values with different superscript letters in the same row are significantly different $(p<0.05)$. Bolded words thorought the table are topic headings. 
Table 6. Effect of experimental diets on total pigments and tocopherol profile ( $\mu \mathrm{g} / \mathrm{g})$ in longissimus lumborum.

\begin{tabular}{|c|c|c|c|c|c|c|}
\hline & \multicolumn{4}{|c|}{ Diets } & \multirow[b]{2}{*}{ SEM } & \multirow[b]{2}{*}{$p$-Value } \\
\hline & Control & $\mathrm{CH}$ & $\mathrm{CH}+\mathrm{R}$ & $\mathrm{CH}+\mathrm{M}$ & & \\
\hline \multicolumn{7}{|l|}{ Pigments } \\
\hline$\beta$-Carotene & n.d & n.d & n.d & n.d & - & - \\
\hline Chlorophyll-a ${ }^{1}$ & 6.87 & 14.1 & 14.1 & 16.4 & 2.92 & 0.107 \\
\hline Chlorophyll-b ${ }^{2}$ & 13.3 & 22.5 & 21.9 & 25.0 & 5.44 & 0.420 \\
\hline Total chlorophylls ${ }^{3}$ & 20.2 & 36.5 & 36.0 & 41.4 & 8.30 & 0.273 \\
\hline Total carotenoids 4 & $3.75^{\mathrm{a}}$ & $7.14^{b}$ & $7.99^{b}$ & $7.51^{b}$ & 0.819 & 0.002 \\
\hline $\begin{array}{l}\text { Total chlorophylls and } \\
\text { total carotenoids } 5\end{array}$ & 23.9 & 43.7 & 44.1 & 48.9 & 8.49 & 0.154 \\
\hline \multicolumn{7}{|l|}{ Tocopherols } \\
\hline$\alpha$-Tocopherol & 1.13 & 1.08 & 0.947 & 1.03 & 0.066 & 0.257 \\
\hline$\gamma$-Tocopherol & 0.025 & 0.024 & 0.026 & 0.027 & 0.001 & 0.217 \\
\hline
\end{tabular}

Dietary treatments: $\mathrm{CH}$, Chlorella vulgaris diet; $\mathrm{CH}+\mathrm{R}, \mathrm{C}$. vulgaris diet supplemented with $0.005 \%$ of Rovabio ${ }^{\circledR}$ Excel AP; $\mathrm{CH}+\mathrm{M}, \mathrm{C}$. vulgaris diet supplemented with $0.01 \%$ of four-CAZyme mixture. ${ }^{1} \mathrm{Ca}=11.24 \mathrm{~A}_{662}-2.04$ $\mathrm{A}_{645} \cdot{ }^{2} \mathrm{Cb}=20.13 \mathrm{~A}_{645}-4.19 \mathrm{~A}_{662} \cdot{ }^{3} \mathrm{Ca}+\mathrm{b}=7.05 \mathrm{~A}_{662}+18.09 \mathrm{~A}_{645} \cdot{ }^{4} \mathrm{Cx}+\mathrm{c}=\left(1000 \mathrm{~A}_{470}-1.90 \mathrm{Ca}-63.14\right.$ $\mathrm{Cb}) / 214 .{ }^{5}(\mathrm{Ca}+\mathrm{b})+(\mathrm{Cx}+\mathrm{c})$; n.d., not detected. ${ }^{\mathrm{a}, \mathrm{b}}$ Values with different superscript letters in the same row are significantly different $(p<0.05)$. Bolded words thorought the table are topic headings.

\section{Discussion}

To the best of our knowledge, this is the first study ever to use C. vulgaris microalga as a feedstuff in piglets' diet, supplemented or not with exogenous enzyme cocktails, such as the Rovabio ${ }^{\circledR}$ Excel AP and the preselected four-CAZyme mixture [10]. In this work, a zootechnical trial was performed along with the determination of pork quality and nutritional traits. The dietary incorporation of $5 \%$ of $C$. vulgaris had no impact on growth performance of piglets. In agreement, Furbeyre et al. [11] using Spirulina and C. vulgaris, both at a supplement level of 1\%, showed no effects over ADFI and ADG in weaned piglets (9.1 to $20 \mathrm{~kg} \mathrm{LW).} \mathrm{The} \mathrm{authors} \mathrm{studied} \mathrm{the} \mathrm{administration} \mathrm{of} \mathrm{the} \mathrm{same} \mathrm{microalgae} \mathrm{via}$ drinking water $(385 \mathrm{mg} / \mathrm{kg} \mathrm{LW})$ and found no effect on growth performance in suckling (4.9 kg LW) and weaned piglets (9.04 kg LW) [11]. Like other studies using microalgae as a dietary supplement, Yan et al. [27] described that 0.1 and $0.2 \%$ dietary incorporation of fermented C. vulgaris in pigs' diets (26.6 to $53.0 \mathrm{~kg} \mathrm{LW}$ ) promoted an increase in the ADG of $655 \mathrm{~g} / \mathrm{d}$ relative to the reference diet. For the first time, Martins et al. [8] used Spirulina as an ingredient ( $10 \%$ of dietary inclusion) and described that the growth performance of piglets was reduced, thus highlighting the need of feed enzymes to enhance the digestive utilization of this microalga. In our study, no significant effects on the growth performance of piglets were found, revealing that the dietary level of $5 \%$. vulgaris did not compromise the productive variables. The exogenous carbohydrases applied had no consequences to the point of a higher level of supplementation being necessary, as advanced by Martins et al. [8].

Regarding meat quality traits, the level of $5 \%$ C. vulgaris incorporation, when combined with the pre-selected four-CAZyme mixture, only affected the oxidative stability of longissimus lumborum at day 8 postmortem (storage at $4{ }^{\circ} \mathrm{C}$ ). After 8 days under refrigeration, the increased TBARS reflect a higher instability of meat from microalga-fed piglets with the four-CAZyme mixture in comparison with the control group. This is likely due to poor radical-scavenging activity of the intrinsic antioxidants for mitigating the lipid oxidation promoted by enhanced $n-3$ PUFA content. TBARS over $0.5 \mathrm{mg}$ malondialdehyde $/ \mathrm{kg}$ of fresh meat are recognized as crucial since, at this level of lipid oxidation, the rancid off-flavors are easily perceived by the consumers [28]. In the current study, only at day 8 of storage, TBARS were above this threshold value. Moreover, TBARS values for the four-CAZyme mixture diet-fed animals were lower than $0.9 \mathrm{mg}$ malondialdehyde $/ \mathrm{kg}$ of meat, proposed by Jayasingh and Cornforth [29] for ground and cooked pork. Martins et al. [8] found that in comparison with the reference diet, the incorporation of $10 \%$ of 
Spirulina in piglets' diet, without enzyme supplementation, increased TBARS at three days of storage under refrigeration. Likewise, data on the oxidative stability of meat did not match the antioxidant power of Spirulina, as in the present case of $C$. vulgaris.

An existing relationship between cooking loss and juiciness in pork was described by Aaslyng et al. [30]. The higher value in cooking loss found in the reference group influenced the lower value of juiciness for the same diet. Sensory attributes such as tenderness and overall acceptability were increased by Rovabio ${ }^{\circledR}$ commercial supplementation relative to the other diets, suggesting that overall consumer acceptability is mostly determined by tenderness. Furthermore, and according to our trained sensory panel, C. vulgaris had no negative effect on meat flavor, thus contributing to consumer's acceptance of this meat.

Feeding piglets with $5 \%$ of $C$. vulgaris, individually or combined with the fourCAZyme mixture, increased DPA and DHA, showing a positive correspondence between $n$ 3 PUFA in the diet and $n-3$ PUFA deposited in longissimus lumborum muscle. $n-3$ long-chain PUFA display health beneficial effects [31]. In fact, several animal and epidemiological reports have proven the advantages of $n-3$ PUFA on cardiovascular disease outcomes [32,33]. Furthermore, the FAO, the WHO, and the American Heart Association recommended EPA (20:5n-3; eicosapentaenoic acid) plus DHA daily intake from 140 to $600 \mathrm{mg} / \mathrm{d}$, depending on the authority guidelines $[34,35]$. However, most Western populations consume an average below $500 \mathrm{mg} /$ day of $n-3$ long-chain PUFA [36]. For instance, piglets' diet receiving $5 \%$ of $C$. vulgaris combined with the four-CAZyme mixture could be a valuable source of these protective fatty acids to both animals and humans. Consistent with our findings, the dietary C. vulgaris at this level of incorporation also produced an increment in $n$-3 PUFA amount in finishing pigs [9]. The enhancement of $n-3$ PUFA content subsequently resulted in a positive decline in $n-6 / n-3$ ratio in muscle with incorporation of $C$. vulgaris in piglets diet. Although the $n-6 / n-3$ ratios were considerably elevated, our data indicate that meat from piglets fed this microalga complies more (around 12.6) with the advised $n-6 / n-3$ ratio (below 4), thus promoting health-protecting cardiovascular effects for consumers [37] and improving meat quality.

A significant increase of total carotenoids in longissimus lumborum muscle was observed in piglets fed C. vulgaris, which reflects diet composition. In fact, the incorporation of this microalga led to higher content of pigments in the diets, in particular about 17 times more total carotenoids if compared with the reference diet. As highlighted by Coelho et al. [9], the transfer of carotenoids from the microalga to the meat adds extra nutritional value to pork. Our data are in accordance with these authors, who also found 2 times higher total carotenoid contents in meat from finishing pigs fed with $5 \%$ of $C$. vulgaris. Similar to the study by Coelho et al. [9], $\beta$-Carotene (pro-vitamin A) was undetected in meat, possibly indicating that this pigment was rapidly metabolized into vitamin A because pigs are unable to synthesize carotenoids.

\section{Conclusions}

The incorporation of $C$. vulgaris at a level of $5 \%$ in the diet does not impair growth performance of piglets or their meat quality traits. In contrast, at this level of dietary inclusion, it seems that an improvement in the nutritional value of pork occurs, in particular through the increment of total carotenoids and $n-3$ PUFA content, which promotes a beneficial $n-6 / n-3$ PUFA ratio for the consumers. Additionally, the supplementation with exogenous enzymes, both the commercial Rovabio ${ }^{\circledR}$ formulation and the pre-selected four-CAZyme mixture, seems to have a minor impact on the multiple parameters assessed. One exception is the increased score for tenderness and overall acceptability of pork from piglets fed C. vulgaris combined with Rovabio ${ }^{\circledR}$. In view of these findings, further research is warranted, focusing in particular on higher levels of $C$. vulgaris incorporation, individually or supplemented with feed enzymes, in order to ascertain whether C. vulgaris is a cost-effective alternative feedstock for livestock production.

Author Contributions: Conceptualization, J.P.B.F. and J.A.M.P.; methodology, C.F.M., J.M.P., C.M.A., M.C., D.M.R., D.C. and P.A.L.; writing—draft preparation, C.F.M., J.M.P., C.M.A. and P.A.L.; writing- 
review and editing, A.M.A., J.P.B.F. and J.A.M.P.; project administration, J.A.M.P.; funding acquisition, J.A.M.P. All authors have read and agreed to the published version of the manuscript.

Funding: This research was funded by FCT-Fundação para a Ciência e a Tecnologia (Lisboa, Portugal), grants number PTDC/CVT-NUT/5931/2014 and UIDB/00276/2020, and by Portugal2020 (Lisboa, Portugal), grant number 08/SI/3399/2015. Authors D.C., J.M.P., and D.M.R. acknowledge funding from FCT, through fellowships SFRH/BD/126198/2016, SFRH/BPD/116816/2016, and SFRH/BD/143992/2019, respectively, and FCT Stimulus of Scientific Employment Program to PAL (DL57/2016/CP1438/CT0007).

Institutional Review Board Statement: ARRIVE Guidelines for in vivo experiments have been followed.

Informed Consent Statement: Not applicable.

Data Availability Statement: The data presented in this study are available on request from the corresponding author.

Acknowledgments: The authors acknowledge Teresa Costa from Indukern, Lda. (Sintra, Portugal), for offering the Rovabio ${ }^{\circledR}$ Excel AP.

Conflicts of Interest: The authors declare no conflict of interest.

\section{References}

1. Food and Agriculture Organization of the United Nations (FAO). The Future of Food and Agriculture: Trends and Challenges; FAO: Rome, Italy, 2017; ISBN 9789251095515.

2. Food and Agriculture Organization of the United Nations (FAO). The State of Food and Agriculture; FAO: Rome, Italy, 2007; ISBN 978-92-5-205750-4.

3. Food and Agriculture Organization of the United Nations (FAO). Food Insecurity in the World; FAO: Rome, Italy, 2011; ISBN 978-92-5-106927-1.

4. Madeira, M.S.; Cardoso, C.; Lopes, P.A.; Coelho, D.; Afonso, C.; Bandarra, N.M.; Prates, J.A.M. Microalgae as feed ingredients for livestock production and meat quality: A review. Livest. Sci. 2017, 205, 111-121. [CrossRef]

5. Garcia-Vaquero, M. Food applications. In Microalgae: Cultivation, Recovery of Compounds and Applications Edited, 1st ed.; Galanakis, C.M., Ed.; Elsevier Science: Cambridge, MA, USA, 2020; pp. 207-232. ISBN 978-0-12-821218-9.

6. Pinto, L.F.R.; Ferreira, G.F.; Tasicc, M. Cultivation techniques. In Microalgae: Cultivation, Recovery of Compounds and Applications Edited, 1st ed.; Galanakis, C.M., Ed.; Elsevier Science: Cambridge, MA, USA, 2020; pp. 1-26. ISBN 978-0-12-821218-9.

7. Sander, K.; Murthy, G.S. Enzymatic degradation of microalgal cell walls. In Proceedings of the American Society of Agricultural and Biological Engineers (ASEBE), Annual International Meeting, St. Joseph, NV, USA, 21-24 June 2009.

8. Martins, C.F.; Assunção, J.P.; Santos, D.M.R.; Madeira, M.S.; Alfaia, C.M.; Lopes, P.A.; Coelho, D.; Lemos, J.P.; Almeida, A.M.; Prates, J.A.M.; et al. Effect of dietary inclusion of Spirulina on production performance, nutrient digestibility and meat quality traits in post-weaning piglets. J. Anim. Physiol. Anim. Nutr. 2021, 105, 247-259. [CrossRef] [PubMed]

9. Coelho, D.; Pestana, J.; Almeida, J.M.; Alfaia, C.M.; Fontes, C.M.G.A.; Moreira, O.; Prates, J.A.M. A High Dietary incorporation level of Chlorella vulgaris improves the nutritional value of pork fat without impairing the performance of finishing pigs. Animals 2020, 10, 2384. [CrossRef] [PubMed]

10. Coelho, D.; Lopes, P.A.; Cardoso, V.; Ponte, P.; Brás, J.; Madeira, M.S.; Alfaia, C.M.; Bandarra, N.M.; Gerken, H.G.; Fontes, C.M.G.A.; et al. Novel combination of feed enzymes to improve the degradation of Chlorella vulgaris recalcitrant cell wall. Sci. Rep. 2019, 9, 5382. [CrossRef] [PubMed]

11. Furbeyre, H.; Milgen, J.; Mene, T.; Gloaguen, M.; Labussière, E. Effects of dietary supplementation with freshwater microalgae on growth performance, nutrient digestibility and gut health in weaned piglets. Animal 2017, 11, 183-192. [CrossRef]

12. Furbeyre, H.; Milgen, J.; Mener, T.; Gloaguen, M.; Labussière, E. Effects of oral supplementation with Spirulina and Chlorella on growth and digestive health in piglets around weaning. Animal 2018, 12, 2264-2273. [CrossRef]

13. Grinstead, G.S.; Tokach, M.D.; Dritz, S.S.; Goodband, R.D.; Nelssen, J.L. Effects of Spirulina platensis on growth performance of weanling pigs. Anim. Feed Sci. Technol. 2000, 83, 237-247. [CrossRef]

14. Fix, J.S.; Cassady, J.P.; Holl, J.W.; Herring, W.O.; Culbertson, M.S.; See, M.T. Effect of piglet birth weight on survival and quality of commercial market swine. Livest. Sci. 2010, 132, 98-106. [CrossRef]

15. Collins, C.L.; Pluske, J.R.; Morrison, R.S.; McDonald, T.N.; Smits, R.J.; Henman, D.J.; Stensland, I.; Dunshea, F.R. Post-weaning and whole-of-life performance of pigs is determined by live weight at weaning and the complexity of the diet fed after weaning. Anim. Nutr. 2017, 3, 372-379. [CrossRef]

16. Association of Official Analytical Chemists International. Official Methods of Analysis, 17th ed.; AOAC International: Arlington, VA, USA, 2000.

17. Noblet, J.; Fortune, H.; Dubois, S.; Henry, Y. Nouvelles Bases D'estimation des Teneurs en énergie Digestible Métabolisable et Nette des Aliments Pour le Porc; INRA: Paris, France, 1989. 
18. Sukhija, P.S.; Palmquist, D.L. Rapid method for determination of total fatty acid content and composition of feedstufs and feces. J. Agric. Food Chem. 1988, 36, 1202-1206. [CrossRef]

19. Prates, J.; Quaresma, M.A.G.; Bessa, R.J.B.; Fontes, C.M.A.; Alfaia, C.M.M. Simultaneous HPLC quantification of total cholesterol, tocopherols and carotene in Barrosã-PDO veal. Food Chem. 2006, 94, 469-477. [CrossRef]

20. Teimouri, M.; Amirkolaie, A.K.; Yeganeh, S. The effects of Spirulina platensis meal as a feed supplement on growth performance and pigmentation of rainbow trout (Oncorhynchus mykiss). Aquaculture 2013, 396, 14-19. [CrossRef]

21. Hynstova, V.; Sterbova, D.; Klejdus, B.; Hedbavny, J.; Huska, D.; Adamab, V. Separation, identification and quantification of carotenoids and chlorophylls in dietary supplements containing Chlorella vulgaris and Spirulina platensis using High Performance Thin Layer Chromatography. J. Pharm. Biomed. Anal. 2018, 148, 108-118. [CrossRef]

22. Grau, A.; Guardiola, F.; Boatella, J.; Barroeta, A.C.; Codony, R. Measurement of 2-thiobarbituric acid values in dark chicken meat through derivative spectrophotometry: Influence of various parameters. J. Agric. Food Chem. 2000, 48, 1155-1159. [CrossRef] [PubMed]

23. Cross, H.R.; Moen, R.; Stanfield, M.S. Training and testing of judges for sensory analysis of meat quality. Food Technol. 1979, 32, $48-54$.

24. Folch, J.; Lees, M.; Stanley, G.S. A simple method for the isolation and purification of total lipides from animal tissues. J. Biol. Chem. 1957, 226, 497-509. [CrossRef]

25. Carlson, L.A. Extraction of lipids from human whole serum and lipoproteins and from rat liver tissue with methylene chloridemethanol: A comparison with extraction with chloroform-methanol. Clin. Chim. Acta 1985, 149, 89-93. [CrossRef]

26. Raes, K.; De Smet, S.; Demeyer, D. Effect of double-muscling in Belgian Blue young bulls on the intramuscular fatty acid composition with emphasis on conjugated linoleic acid and polyunsaturated fatty acids. Anim. Sci. 2001, 73, 253-260. [CrossRef]

27. Yan, L.; Lim, S.U.; Kim, I. Effect of fermented Chlorella supplementation on growth performance, nutrient digestibility, blood characteristics, fecal Microbial and fecal noxious gas content in growing pigs. Asian Australas. J. Anim. Sci. 2012, 25, $1742-1747$. [CrossRef]

28. Wood, J.D.; Enser, M.; Fisher, A.V.; Nute, G.R.; Sheard, P.R.; Richardson, R.I.; Hugher, S.I.; Whittington, F.M. Fat deposition, fatty acid composition and meat quality: A review. Meat Sci. 2008, 78, 343-358. [CrossRef]

29. Jayasingh, P.; Cornforth, D.P. Comparison of antioxidant effects of milk mineral, butylated hydroxytoluene and sodium tripolyphosphate in raw and cooked ground pork. Meat Sci. 2003, 66, 83-89. [CrossRef]

30. Aaslyng, M.D.; Bejerholm, C.; Ertbjerb, P.; Bertram, H.C.; Andersen, H.J. Cooking loss and juiciness of pork in relation to raw meat quality and cooking procedure. Food Qual. Prefer. 2003, 14, 277-288. [CrossRef]

31. Mason, R.P. New insights into mechanisms of action for omega-3 fatty acids in atherothrombotic cardiovascular disease. Curr. Atheroscler. Rep. 2019, 21, 2. [CrossRef]

32. Endo, J.M.D.; Arita, M. Cardioprotective mechanism of omega-3 polyunsaturated fatty acids. Review. J. Cardiol. 2016, 67, 22-27. [CrossRef] [PubMed]

33. Kris-Etherton, P.M.; Richter, C.K.; Bowen, K.J.; Skulas-Ray, A.C.; Jackson, K.H.; Petersen, K.S.; Harris, W.S. Recent clinical trials shed new light on the cardiovascular benefits of omega-3 fatty acids. Methodist Debakey Cardiovasc. J. 2019, 15, 171-178. [CrossRef] [PubMed]

34. Molendi-Coste, O.; Legry, V.; Leclerq, I.A. Why and how meet n-3 PUFA dietary recommendations? Gastroenterol. Res. Pract. 2011, 2011, 364040. [CrossRef]

35. Aranceta, J.; Pérez-Rodrigo, C. Recommended dietary reference intakes, nutritional goals and dietary guidelines for fat andatty acids: A systematic review. Br. J. Nutr. 2012, 107 (Suppl. 2), S8-S22. [CrossRef] [PubMed]

36. Martins, D.A.; Custódio, L.; Barreira, L.; Pereira, H.; Ben-Hamadou, R.; Varela, J.; Abu-Salah, K.M. Alternative sources of n-3 long-chain polyunsaturated fatty acids in marine microalgae. Rev. Mar. Drugs 2013, 11, 2259-2281. [CrossRef] [PubMed]

37. HMSO. Nutritional Aspects of Cardiovascular Disease; Department of Health Report on Health and Social Subjects, No. 46; Department of Health: London, UK, 1994; pp. 37-46. 